Review

\title{
Exploring the Potential for Concentration of Nutrients from Urine Using Solar Evaporation and Carbon Dioxide Trapping of Ammonia
}

\author{
${ }^{1}$ Tesfamariam Y. Debessai, ${ }^{2}$ Ababu T. Tiruneh and ${ }^{3}$ Gabriel C. Bwembya \\ ${ }^{1}$ Department of Chemistry, University of Eswatini, Kwaluseni, Eswatini, South Africa \\ ${ }^{2}$ Department of Environmental Health Science, University of Eswatini, Mbabane, Eswatin, South Africa \\ ${ }^{3}$ Department of Chemistry, University of Eswatini, Kwaluseni, Eswatini, South Africa
}

\author{
Article history \\ Received: 03-09-2019 \\ Revised: 13-10-2019 \\ Accepted: 25-10-2019 \\ Corresponding Author: \\ Ababu T. Tiruneh \\ Department of Environmental \\ Health Science, University of \\ Eswatini, Mbabane, Eswatin, \\ South Africa \\ Email: ababute@gmail.com
}

\begin{abstract}
Nutrients derived from urine such as nitrogen, phosphorous and potassium constitute valuable sources of fertilizers needed for growing plants and as alternatives to commercial fertilizers. Concentration of nutrients available from urine provides advantages of reducing the volume of transportation, the health risk and making nutrient application to soil stable and suitable. An exploratory review of a possible technology for concentration of nutrients from urine using solar power assisted evaporation and carbon dioxide trapping of evaporated ammonia is discussed in this paper as a potentially viable technology for concentrating nutrients from urine as well as another sequestration option to reduce carbon foot print in the environment.
\end{abstract}

Keywords: Nutrient Concentration, Urine Fertilization, Agriculture, Struvite, Ammonium Bicarbonate, Nitrogen, Phosphorous

\section{Introduction}

The need for production of nutrients such as nitrogen, phosphorus and potassium (NPK) needed for food growth is increasing in this modern time because of the increase in the world population and the standard of living of people. By the end of 2050, the world's population is expected to reach 9 billion (UN, 1999). As pressure on land increases, less fertile land is used that requires use of fertilizers. Crops grown for bio fuels also increase the fertilizer need.

The value of nutrients derived from urine, such as those collected from urine diversion dry toilet (UDDT), has been repeatedly demonstrated (Heinonen-Tanski and Van Wijk-Sijbesma, 2005; Tidåker et al., 2007; Karak and Bhattacharyya, 2011; Makaya et al., 2014). Such nutrients were found to be less costly alternatives to commercial fertilizers (Esrey et al., 2001). Nutrients available from urine are easily absorbed although they can also be easily leached away from the soil (except crystal forms such as Struvite) by water compared to organic compost (Keshay and Chen, 2011). Urine is selfsterilized at a pH of around 9.0 following hydrolysis, largely eliminating health concerns (Höglund et al., 2002). Storage of urine should be in undiluted form to prevent pathogen regrowth and preserve the nutrient concentration at high level (Vinnerås et al., 2008).
Concentration of nutrients from urine would be attractive to reduce the transportation cost especially in large scale agricultural application to distant sites from the urine source. A wide range of urine concentration techniques are available including electro-dialysis, Nano- filtration (Pronk and Kone, 2010) and Struvite, although Struvite excludes potassium and large part of the nitrogen from concentration (Ronteltap et al., 2010; Antonini et al., 2011; Morales et al., 2013). Other nutrient concentration techniques include ion exchange for phosphorous (Sendrowski and Boyer, 2013), ammonia concentration by zeolite adsorption (Beler-Baykal et al., 2004; Ganrot et al., 2007) and ammonia stripping (Antonini et al., 2011; Behrendt et al., 2002; Başakçilardan-Kabakci et al., 2007; Siegrist et al., 2013).

Concentration of nutrients from urine by evaporation requires acidification to prevent ammonia loss. The acid requirement would be high as urine $\mathrm{pH}$ is around 9.0 (Udert and Wächter, 2012). Alternative proposals include biological nitrification of ammonia (Pronk and Cone, 2010) and concentration of ammonia evaporated from urine with sulphuric acid (Gulyas et al., 2014) which is expensive process. The different concentrations techniques have varying degree of concentration some partial, some complete. A urine concentration technique with carbon dioxide trapping of solar evaporated ammonia potentially results in ammonium bicarbonate 
product together with residue left from evaporation that can be suitably combined with the ammonium carbonate to provide needed nutrients for plant growth. The evaporation can be performed with renewable energy source such as using solar concentrators (Tiruneh et al., 2017; Pronk and Kone, 2010; Antonini et al., 2012b).

\section{Urine as Nutrient Source}

Urine is a component of wastewater discharge storing $80 \%$ of nitrogen and $50 \%$ of phosphorous (Maurer et al., 2006; Larsen et al., 2009). Wastewater has both organic and ammonia nitrogen while phosphorus is in the organic and orthophosphate form. It is easier to extract nutrients from urine rather than wastewater from the viewpoints of technology, health and environmental hazards (Tice, 2014). Nitrification and nitrate reduction as well as anaerobic/anoxic phosphorous reduction form wastewater require extra volume, high residence time and sludge recycling. Separating urine form wastewater during use eases the disposal requirement away from unaffordable conventional technologies particularly for developing countries (Larsen et al., 2009; Etter et al., 2011). Wastewater containing high volume of flush water renders the nutrients dilute making their recovery difficult (Höglund, 2001).

Source separation of urine and its reuse assists in resource recovery and reducing pollution as a result of linear disposal of wastewater (Schuen et al., 2009). Although urine contains only $1 \%$ of the volume of wastewater, it contains most of the nutrients thereby providing economical alternative to commercial fertilizers (Ronteltap, 2009). The per capita daily generation of urine is 1.8-1.5 lit/day, $95 \%$ of which is water and the remaining $5 \%$ contains nitrogen, phosphorus and other micronutrients. The urine generated from a single person can cover the nutrient requirement of 300-400 $\mathrm{m}^{2}$ of land to a level application of $50-100 \mathrm{~kg} / \mathrm{ha}$ of nitrogen (Feineigle, 2011). Urine application should be controlled as otherwise excess application of urine increases the salinity as well as soil $\mathrm{pH}$ compared to commercial fertilizers (Srinivasamurthy, 2009). The composition of typical human urine is given in Table 1.

Table 1: Composition of urine

\begin{tabular}{llll}
\hline Parameter & Range & Parameter & Range \\
\hline $\mathrm{pH}$ & $4.26-6.81$ & $\mathrm{HCO}_{3}^{-}(\mathrm{meq} / \mathrm{L})$ & $5.12-16.64$ \\
$\begin{array}{l}\text { Electrical } \\
\text { condu ctivity } \\
(\mathrm{dS} / \mathrm{cm})\end{array}$ & $5.64-8.75$ & $\mathrm{Cl}^{-}(\mathrm{meq} / \mathrm{L})$ & $22.72-38.76$ \\
$\mathrm{~N}(\%)$ & $0.21-0.55$ & & \\
$\mathrm{P}_{2} \mathrm{O}_{5}(\%)$ & $0.11-0.3$ & $\mathrm{Na}(\%)$ & $0.12-0.34$ \\
$\mathrm{~K} 2 \mathrm{O}(\%)$ & $0.12-0.25$ & $\mathrm{Fe}(\mathrm{mg} / \mathrm{L})$ & $16.2-23.8$ \\
$\mathrm{Ca}(\mathrm{meq})$ & $98.60-164.80$ \\
$\mathrm{Mg}(\mathrm{meq} / \mathrm{L})$ & $6.00-26.00$ & $\mathrm{Mn}(\mathrm{mg} / \mathrm{L})$ & $17.8-27.00$ \\
$\mathrm{~S}(\%)$ & $0.07-0.22$ & $\mathrm{Cu}(\mathrm{mg} / \mathrm{L})$ & $41.8-48.78$ \\
\hline
\end{tabular}

Source: Srinivasamurthy (2009)

\section{Sources and uses of Nitrogen and Phosphorus}

Nitrogen is abundant in the atmosphere, with atmospheric air consisting of $78 \%$ by mass nitrogen. The gaseous state of nitrogen means that its abundance is spread over the whole world. However, nitrogen molecule is strong, triple-bonded with a strong bonding energy among the three electron pairs of the two nitrogen atoms. It is, therefore relatively inert with little engagement in chemical reactions (Maurer et al., 2002). Nitrogen, however, is important in living organisms where by the DNA, RNA and proteins in all living cells of organisms contain nitrogen. Nitrogen is converted to chemically reactive forms by biological fixation (blue green algae) and chemically through the Haber-Bosch process (hydrogen reacts with ammonia) that is used for commercial production of fertilizers.

Phosphorous, discovered in 1669 by Henning Brandt (Bryant, 2004), is also a major building block of DNA, nerve cells, brain, bone and teeth. It also plays key role in energy production where phosphorous is part of the ATP and ADP that are sources of energy in biochemical reactions. Naturally, the source of phosphorous is limited in phosphate rocks, $80 \%$ of which is used for fertilizers (Steén and Steen, 1998).

\section{Why Concentrate Nutrients from Urine}

The high volumes of urine generated from toilets are difficult to transport to the place of application and difficult to store for long because of odour problems. Urine collected from crowded settlements need to be transported longer distance to find a land where it can be applied for growing plants. Direct application of urine on plants faces objection due to the odour and the risk to plant growth (Miso and Sphuler, 2009). Strong smell is produced by ammonia during application of urine to soil which can lead to eye irritation; a discouraging factor among farmers. Ammonia is also lost from the soil by volatilization (Tilley et al., 2009). Compared to nutrients applied in solid form, application of urine in liquid form facilitates leaching of nutrients from soil, enhancing eutrophication problems (Tilley et al., 2009). Direct application reduces soils nitrogen fixing capacity (Di et al., 2002). Micro pollutants (such as pharmaceuticals) and salts can also accumulate with time (Maurer et al., 2002).

\section{Technologies Employed for Nutrient Concentration from Urine}

Several technologies are in use for recovering nutrients from urine. These include: Ammonia stripping/evaporation, Zeolite adsorption, Struvite precipitation, Duck weed ponds/aquaculture, Aquaponics, Isobutylaldehyde-Diurea (IBDU) Precipitation, Concentrated liquid fertilizer and precipitation using Bittern, Electro-dialysis, membrane and ozonation processes (Chariar et al., 2011). A brief description of these technologies is presented below: 


\section{Ammonia Stripping/Evaporation}

Ammonia stripping occurs through steam whereby the ammonia is being trapped through condensation of steam, or, by air stripping process in which the ammonia-laden air is washed with acid (Thorndahl, 1993). In the evaporation process, the evaporated ammonia is trapped with acid while a residue of other nutrients is left after evaporation. It is shown that 85$99 \%$ evaporation of ammonia occurs at $85^{\circ} \mathrm{C}$ heating for 72 h (Gulyas et al., 2014). Stripping by contrast reportedly has low percentage recovery, being between 3 and $12 \%$ (Pinnekamp et al., 2007) in which air was used for stripping followed by wet scrubbing with sulphuric acid.

\section{Zeolite Stripping}

Zeolite also called Clinoptilolite $\left(\mathrm{Na}_{2}, \mathrm{~K}_{2}, \mathrm{Ca}\right)_{3} \mathrm{Al}_{6} \mathrm{Si}_{30} \mathrm{O}$. $24 \mathrm{H}_{2} \mathrm{O}$ ) is a known cation exchanger with particular affinity for ammonium. Phosphorous is adsorbed while ammonium can be trapped through ion exchange (Garnot, n.y.). According to Tiruneh et al. (2011), through bench scale laboratory experiments, it was found that, after being dissolved and washed by running strong sulphuric acid, $920 \mathrm{mg} / \mathrm{l}$ of $\mathrm{NH}_{4}{ }^{+}$as solid precipitate and $1287 \mathrm{mg} / \mathrm{l}$ of $\mathrm{NH}_{4}{ }^{+}$in ionic form were found in the Struvite and Zeolite adsorption processes respectively from $1250 \mathrm{~mL}$ of Solar concentrated urine.

\section{Struvite Precipitation}

Struvite $\left(\mathrm{MgNH}_{4} \mathrm{PO}_{4} \cdot 6 \mathrm{H}_{2} \mathrm{O}\right)$ is a white odourless solid powder and a good fertilizer. Urine stored for long period shows traces of Struvite. Struvite spontaneously precipitates at $\mathrm{pH}$ of 9 during hydrolysis or more generally in the $\mathrm{pH}$ range of 7 to 11 with a $1: 1: 1$ molar ratio between magnesium, ammonium and phosphate (Ronteltap, 2009; Doyle and Parsons, 2002). However, minimum solubility of Struvite is achieved at $\mathrm{pH}=9$ (Münch and Barr, 2001; Nelson et al., 2003). Struvite's solubility and reaction rate is influenced by temperature, the solubility product increasing with temperature (Durrant et al., 1999; Aage et al., 1997). Higher temperature, therefore, reduces Struvite formation while encouraging ammonia volatilization. Struvite formation from urine is limited by phosphorus and more especially by magnesium requiring extra supplementing of magnesium. One $\mathrm{Kg}$ of Struvite is generated from 500 litres of urine (The Swiss Federal Institute of Aquatic Science and Technology, (EAWAG, 2009). The precipitated Struvite can be separated using nylon or cotton bag (Etter et al., 2011). Stored urine produces Struvite better than fresh urine (Musabaev, 2015). Struvite provides $50 \%$ of phosphorous, part of nitrogen and all of magnesium needed for plant growth (Antonini et al., 2012a). Some studies indicated that the supply of phosphorous from Struvite was better than commercial fertilizers (Ryu et al., 2012; Ghosh et al., 1996).

Struvite with external magnesium supplement precipitates up to $99 \%$ of phosphorous but only part of nitrogen from urine (Ronteltap, 2009). Additional nitrogen source may be needed. Struvite can also increase the soil magnesium content as well as the $\mathrm{pH}$ to the extent of retarding plant growth (Miso and Sphuler, 2009).

\section{Duckweed Weed Ponds}

Duckweed aquaculture can recover nitrogen and phosphorous from wastewater streams. In addition, other nutrients are also absorbed including calcium, sodium, potassium, magnesium, carbon and chloride from wastewater (Les et al., 2002).

\section{Aquaponics}

Aquaponics combines hydroponics (plant grown without soil) and aqua culture. The system proposed is that, in place of aquaculture one could use diluted human urine for the supply of nutrients ( $\mathrm{N}, \mathrm{P}$ and $\mathrm{K}$ ) to plants (Karli, 2010).

\section{Isobutylaldehyde-Diurea (IBDU) Precipitation}

IBDU concentration of urine is a form of precipitation that requires fresh urine in the form of urea reacting with Isobutylaldehyde (IB).

\section{Precipitation Using Bittern}

Precipitation with bittern involves using the remaining liquid after salt extraction from brine much like Struvite, aided by the high magnesium content of brine (Lee et al., 2003). Bittern is also a cheaper source of magnesium (Prabhu and Mutnuri, 2014).

\section{Electro-Dialysis, Membrane and Ozonation Processes}

Electro-dialysis process exposes ion-exchange membranes alternately to direct current field whereby the cations and anions migrate towards the cathode and anode electrodes respectively. Phosphorous is concentrated readily through electro dialysis (Zhang et al., 2012). Bipolar membranes aid the dissociation of water and salt to ion (Bailly, 2002). The combined process of electro dialysis with ozonation enables separation of nutrients in the concentrate in the form of phosphoric acid and ammonium hydroxide (Fewlwss, 2015; Wang et al., 2013).

Reverse osmosis and Nano filters show high rejection of nutrients from urine (Maurer et al., 2006; Pronk et al., 2006; Blöcher et al., 2012; Niewersch et al., 2014). However, membranes are prone to bio fouling (Xie et al., 2015). Membrane distillation is a thermally assisted process that allows water vapour to pass across the membrane due to difference in partial pressure of water 
while preventing water due to the membrane's hydrophobic properties (Alkhudhiri et al., 2012). Ammonia is recovered in the permeate (Zarebska et al., 2014). Membranes are also combined with bio reactors, creating microbial electrolysis cells. Bacteria oxidise organics and carry the electrons generated to the anode. The application of current allows migration of electrons to cathode where hydrogen is released (Liu et al., 2005; Rozendal et al., 2006; Logan et al., 2008). By placing membranes between the electrodes $\mathrm{NH}_{4}{ }^{+}$and $\mathrm{HPO}_{4}{ }^{2-}$ can be concentrated from the diluted urine (Tice, 2014).

\section{Evaluation of Existing Nutrient Concentration Technologies from Urine}

According to Rahman et al. (2011), Struvite precipitation is found to be most feasible followed by Bittern and zeolite adsorption. However Struvite has limited nitrogen with non-optimal $\mathrm{N}$ : $\mathrm{P}$ ratio of $1: 1$. It also requires magnesium supplementation whose accumulation in soil can in turn create problems for plant growth. Evaporation and stripping process are energy intensive and require expensive chemicals for wet scrubbing of the ammonia. Ion exchange processes require regeneration of the media once exhausted. In addition, only part of the nutrients is trapped. They also suffer from co-adsorption from other non-target ions that limit their capacity. Membrane processes offer the potential for complete rejection and high nutrient concentration. However, they are expensive and are subjected to membrane fouling. Membranes are relatively new and emerging technologies for which there is limited information available regarding their potential (Mehta et al., 2015).

\section{Health Risks Related to Direct Application of Urine}

Despite the presence of some risk of microbial contamination of urine, it rarely constitutes a significant public health concern (Höglund, 2001). The human urine is sterile in bladder but picks up bacteria during transport out of the human body (Tortora et al., 1992). Although diseases such as leptospirosis are transmitted by urine from infected animals, human urine is not an important source (Feachem et al., 1983; CDC, 2000). S. typhi and $S$. paratyphi may occur through excretion in urine but the urine-oral route of transmission is unusual. Schistosoma haematobium eggs may be excreted in urine but the risk is low due to the limited life cycle. Mycobacterium tuberculosis and Mycobacterium Bovis may be excreted in urine (Grange and Yates, 1992) but tuberculosis is mainly transmitted through air.

Urine has a sterile environment with high $\mathrm{pH}$ during storage which inactivates pathogen found through cross contamination. Gram-negative bacteria such as Campylobacter and Salmonella are rapidly inactivated in urine. However, the protozoa Cryptosporidium parvum requires storage period of about one month for its inactivation at $20^{\circ} \mathrm{C}$ (Höglund and Stenström, 1999). Viral inactivation requires longer period of storage which may be up to or longer than 3 months (Höglund, 2001). Heavy metals may be introduced into soil during urine application but they occur in low concentrations as to cause public health risk (Jönsson et al., 2000). Limited public health risk also exists due to micro pollutants such as hormones and pharmaceuticals (Ronteltap, 2009). However, nutrient concentration techniques involving heating eliminate pathogens while destroying the hormones and pharmaceutical structures that pose health risk. Struvite precipitation for example excludes hormones and pharmaceuticals, reducing the public health risk.

\section{Solar Concentration Technology as a Source of Energy for Ammonia Volatilization}

Solar concentrators take advantage of the energy readily available from the sun and are used for wide range of applications such as water heating, distillation, solids concentrations, sterilization, etc. Solar concentrators also have the advantage of being renewable energy resources that do not pollute the environment. They also provide competitive cost advantage over other sources of energy such as fuel and electric powers generated by conventional means. Solar concentrators can be of the imaging or non-imaging types (Mansi et al., 2013) The Compound solar Concentrator (CPC) is a non-imaging type of concentrator that concentrates sun ray from a large surface onto a much smaller absorber surface. The CPC technology developed over time since the 1960s and there is a wealth of information available on its performance and diverse range of applications (Winston, 1974; Baranov, 1965; Baranov and Melnikov, 1966; Baranov, 1967; Ploke, 1967; Hinterberger and Winston, 1966a; 1966a; Winston, 1970). Modifications have been made for second stage enhancement of solar concentration typically applied for complete degradation of wastes (Sanchez et al., 2014). The CPC has the advantage of concentrating all the rays that fall on it without the need to make adjustment to track the sun. However, such technology has limited angle of acceptance of the sun ray and do not work the entire day. The maximum concentration is inversely related to the angle of acceptance, an argument that is validated by the thermodynamic limits to solar ray concentrations (Rabl 1976a; 1976b; Winston et al., 2005). CPC concentrators for heating purposes are claimed to be able to give working temperature in the range $80-100^{\circ} \mathrm{C}$ for non-evacuated tubes and $100-200^{\circ} \mathrm{C}$ for absorbers with evacuated tubes.

An example of a modified CPC design that is modified to increase the angle of acceptance is illustrated in Fig. 1, which consists of an extended four wing 
system of solar concentrators different from the traditional two truncated CPC design. (Tiruneh et al., 2016). This modified design is also proposed a suitable concentration device for providing the heat needed to volatilize the ammonia from urine in the ammonium bicarbonate concentration generation from urine. Referring to Fig. 1, during the early hours of the day the right most extended wing of the concentrators sun ray to the outer surface of the absorber. This concentration is carried out by the left most extended wing during the later hours of the day. As the sun progresses to noon in between morning and afternoon the middle wings concentrate the sun ray to the inside of the absorber.

An alternative design of a modified four wing concentrator is shown in Fig. 2 in which the absorber surface is a simplified flat plate. In this particular design the focal points of the two internal reflectors coincide and are locate at the center of the absorber surface. On the other hand the outer wings are pushed outward. In other words, in Fig. 2, the right side outer wing focal point is pushed from $b$ to a while the left side outer wing's focal point is pushed from $\mathrm{c}$ to $\mathrm{a}$.



Fig. 1: Profile sketch of a four wing compound parabolic collector with v-shaped absorber

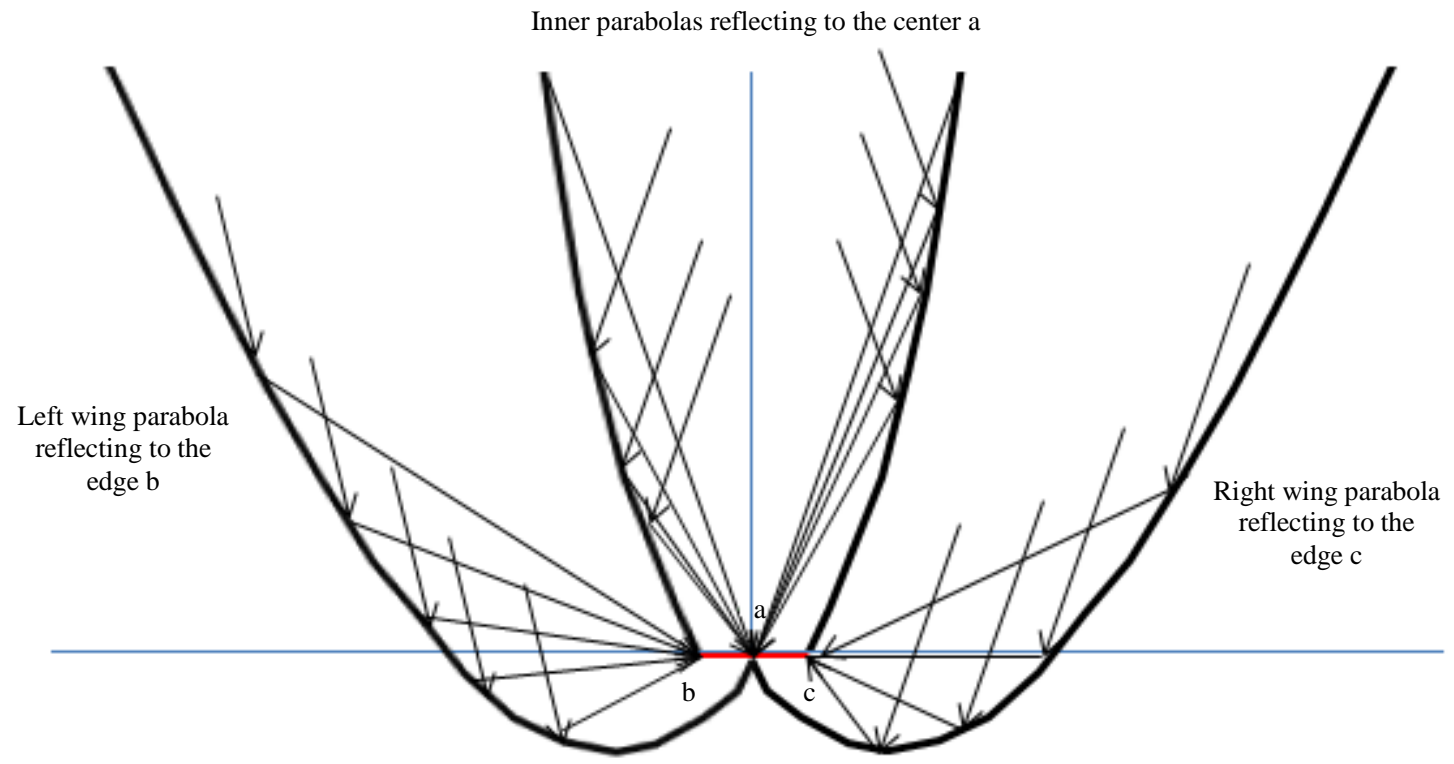

Fig. 2: Alternative profile of compound parabolic concentrator with flat-base absorber 
Experience of application of the modified four wing solar concentrator for heating and sanitization of recycled waste products showed successful results (Tiruneh et al., 2016). The four-wing CPC was able to generate temperature in the range of between $80^{\circ} \mathrm{C}$ $100^{\circ} \mathrm{C}$ during most hours of the day. This also translates to enhanced performance because of the extended period of trapping of the sun radiation. The extended period of absorption of this modified design is an advantage although it is apparent that during the early morning and late afternoon the sun is at a distance and the intensity of sun radiation is reduced. Nonetheless, still significant absorption of the sun radiation is achieved even in these periods. The modified four wing CPC designed is especially suitable for concentrating nutrients from urine because of the greater thermal conductivity of the urine liquid and the low volume applied compared to dry faecal matter from toilets. Experiments for concentrating the ammonia and phosphorous from urine using the solar concentrator were made in which a solid Struvite crystal was formed in the presence of additional magnesium added to the urine using magnesium oxide crystals. The urine was simply poured on the absorber surface which also contains the dolomite solids. The excess ammonia evaporated leaving a residue that contains also solid organic reside from urine as well as some salts.

Application of the solar concentrator to sanitization of solid faecal matter from dry toilets showed temperature up to $80^{\circ} \mathrm{C}$ could be attained in the solid matter for extended period of time. Examination of both urine and faecal matter products after sanitization using the solar concentrator show absence of faecal coliforms in all the samples tested.

\section{Exploring the Need for Further Technology of Nutrient Concentration from Urine}

While concentration of nutrients from urine is an important process that can simplify the application and use of urine for fertilizers, the technical and economic factors may act as constraints when choosing a suitable method for nutrient concentration. Some concentration techniques such as Struvite for example require additional supplementation of magnesium whereas the level of concentration is constrained by the Struvite component ratios and such molar ratio of Struvite components may not provide the optimum nutrient ratios needed for plant growth. Excess magnesium and $\mathrm{pH}$ are also mentioned as possible side effects that can limit plant growth.

Adsorption with zeolite may require higher quantity of the zeolite cation exchanger, especially if the zeolite itself is to be applied as fertilizer. Otherwise, the adsorbed ammonium needs to be washed with the application of strong acid solutions such as sulphuric acid. It may also be necessary to adjust the $\mathrm{pH}$ in order to optimize the adsorption of ammonium ion. Zeolite only leads to ammonium adsorption and should be combined with other methods if other nutrients such as phosphorus and potassium are to be concentrated. Other concentration methods such as electro dialysis are high technology applications and may not always be feasible from cost and technical requirements point of view.

Concentration of urine using evaporation is a feasible technique but requires prevention of ammonia loss such as by the addition of excess quantities of acid so that the ammonium ion stays in solution. Otherwise, the loss of ammonia may not lead to optimum condition for nutrient concentration.

A suitable technical design that overcomes the problem of ammonia loss or the need for excess acid addition would be one that involves separate capture of ammonia using cheap carbon dioxide source. Once the ammonia is completely captured, the remaining volume reduction can be carried out by continuing evaporation at higher temperature. With this arrangement, it is anticipated that optimum condition for nutrient concentration can be created without requiring addition of chemicals or without the technical sophistication that may be difficult to afford or operate.

Ammonium Bicarbonate: Property, Production and use as Fertilizer

Ammonium bicarbonate $\left(\mathrm{NH}_{4} \mathrm{HCO}_{3}\right.$ or $\left.\mathrm{NH}_{5} \mathrm{CO}_{3}\right)$ is a mildly basic inorganic compound. It is produced by passing carbon dioxide in solution containing ammonia (Othmer, 1992):

$$
\mathrm{CO}_{2}+\mathrm{NH}_{3}+\mathrm{H}_{2} \mathrm{O} \rightarrow \mathrm{NH}_{4} \mathrm{HCO}_{3}
$$

The production of ammonium bicarbonate is favoured when the molar ratio between ammonia and carbon dioxide is 1.0 or greater (Liu et al., 2004):

$$
\begin{aligned}
& \mathrm{CO}_{2}+\mathrm{NH}_{3}+\mathrm{H}_{2} \mathrm{O} \rightarrow \mathrm{NH}_{4} \mathrm{HCO}_{3} \ldots . .\left[\mathrm{NH}_{3} / \mathrm{CO}_{2}\right]=1.0 \\
& \mathrm{CO}_{2}+2 \mathrm{NH}_{3}+\mathrm{H}_{2} \mathrm{O} \rightarrow\left(\mathrm{NH}_{4}\right)_{2} \mathrm{CO}_{3} \ldots . .\left[\mathrm{NH}_{3} / \mathrm{CO}_{2}\right]=2.0
\end{aligned}
$$

Ammonium bicarbonate forms through crystallization that can be filtered out, washed and dried in air. Ammonium bicarbonate is a white crystalline solid with a density of $1.59 \mathrm{gm} / \mathrm{L}$, melting point of $41.9^{\circ} \mathrm{C}$ and is water-soluble. It is stable at $25^{\circ} \mathrm{C}$ but decomposes above $36^{\circ} \mathrm{C}$ into ammonia, carbon dioxide and water endothermically:

$$
\mathrm{NH}_{4} \mathrm{HCO}_{3} \rightarrow \mathrm{NH}_{3}+\mathrm{CO}_{2}+\mathrm{H}_{2} \mathrm{O}
$$

Ammonium bicarbonate was manufactured as fertilizer in China but later replaced with other fertilizers. During application of ammonium bicarbonate, $\mathrm{NH}_{4}{ }^{+}$is 
absorbed by the soil and converted to nitrate. The $\mathrm{CO}_{2}$ is also needed by plants. The weakness lies in lack of stability at high temperature through ammonia volatilization. Subsurface or deep soil application is suggested to reduce ammonia volatilization.

\section{Proposed Technique for Ammonia Trapping from Urine Using Bicarbonate Chemistry}

Current technology of sequestering carbon dioxide emissions include absorption tower in which ammonium in solution wet scrubs the carbon dioxide gas. Such techniques suffer from tower packing problems due to lumps of ammonium bicarbonate cakes, ammonia vapour loss with flue gas and low rate of $\mathrm{CO}_{2}$ absorption (Zhuang et al., 2012). However, a technique that may be more relevant and applicable for producing ammonium bicarbonate from urine is a process whereby ammonia is existing and is dissolved in water and the carbon dioxide is bubbled through the solution containing ammonia (liquid bubbling column). In such a process, ammonium bicarbonate is produced more sustainably with low ammonia slip into the carbon dioxide gas system.

Figure 3 shows an example of such system that utilizes a source of carbon dioxide compressed in a cylinder. The cylinder is fitted with a valve as well as flow or pressure regulator to control the amount of carbon dioxide fed into the reactor. The bubble reactor is where the carbon dioxide and ammonia both of which are in gas form and are dissolved in water, react. The bubble reactor is kept in thermostat controlled constant temperature water bath in order to regulate the temperature at which precipitation of ammonium bicarbonate occurs. Fresh urine collected and containing typically 4 grams per litre of ammonia after the process of hydrolysis, which occurs naturally, is heated to a temperature between 80 and 90 degree Celsius in order to volatilize the ammonia out of solution.

The $\mathrm{pH}$ of the urine may further be increased by the addition of calcium hydroxide although this is considered an optional step but nevertheless can be explored further through research. The reaction for trapping ammonia as ammonium bicarbonate is considered complete once the ammonia is volatilized form the urine solution to the maximum limit as influenced by the reaction conditions such as heating temperature and the $\mathrm{pH}$ of the urine in the bubble reactor. The remaining solution in the urine is boiled further in order to concentrate the residual nutrients such as potassium, phosphorus and possibly some of the ammonium ion that could not be volatilized through the earlier, ammonia volatilization process. It is anticipated that this final process of boiling eliminates any pathogens resident in the urine either from the urine itself or from cross contamination with faecal material. Furthermore, pharmaceutical and cytotoxic agents may be degraded by such thermal process, hence reducing the associated risks from them.

\section{Objective and Study Design for Ammonia Trapping from Urine Using Bicarbonate Chemistry}

The objective of setting up technical design for ammonia trapping from urine using evaporation and bicarbonate chemistry centres around evaluating the technical and cost efficiency of $\mathrm{CO}_{2}$ capture of ammonia and the nutrient value that can be derived from the process. Different sources of cheap carbon dioxide sources can be tried for such design. Operational parameters such as $\mathrm{pH}$, temperature, etc., can be optimised to obtain stable, maximum crystallisation and ammonia capture. In addition, the extent of ammonia captured and the proportion of evaporated residues that can be combined with ammonium carbonate crystal produced can be explored for maximum yield of plants grown with such products while minimising the effects of undesirable salts present in the evaporated residue.

It is anticipated that this form of nutrient concentration through evaporation combined with carbon dioxide capture of ammonia offers technically simpler and economically attractive alternative to a number of available nutrient concentration technologies. The traditional setup of industrial production of ammonium bicarbonate fertilizer is using atmospheric air as source of nitrogen whereas methane is employed as source of hydrogen. The two ingredients are reacted through a high temperature catalytic reaction to produce ammonia. Such technological setup is not directly transferrable to application for concentrating nutrients from urine. In the case of urine, ammonia is readily available and need only be trapped. It is, therefore, necessary to design a system of nutrient trapping in order to determine the feasibility of concentrating nutrients as well as evaluate the performance of the setup under different environmental conditions such as $\mathrm{pH}$, temperature, source of $\mathrm{CO}_{2}$, etc.

A feasible technical setup involves a bubble reactor in which the ammonia volatilised from urine by heating process will be made to react with carbon dioxide in the bubble reactor. The reaction produces ammonium bicarbonate solid. The urine is heated further in order to concentrate the remaining nutrients. Fresh or stored samples of urine needed for the experimental trials should be collected possibly from available urine diversion dry toilets. The extent of nutrient concentration obtained should be determined by analysing the captured nutrients such as nitrogen, phosphorus and potassium. The constituents of urine used in the experiments should also be determined using established chemical procedures. 


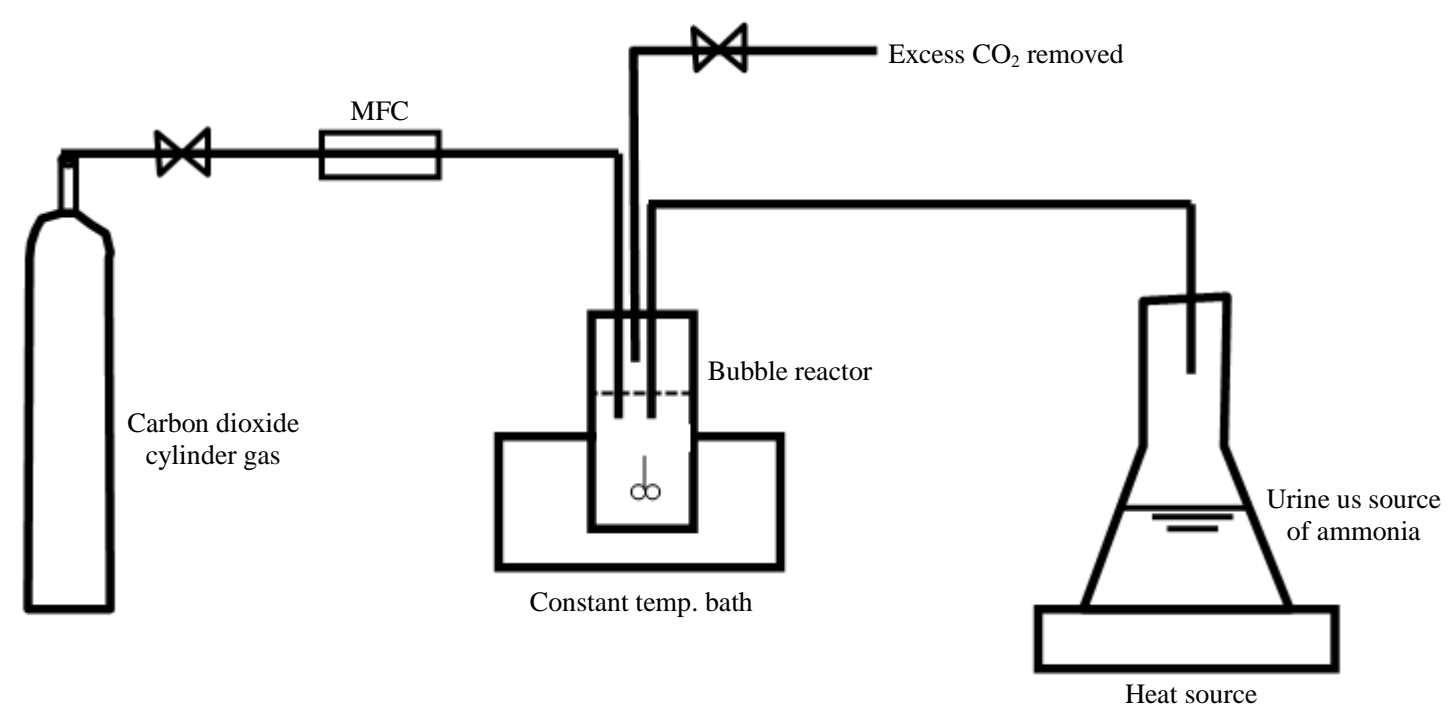

Fig. 3: A bubble reactor for the production of ammonium bicarbonate from urine and carbon dioxide gas supplied from cylinder

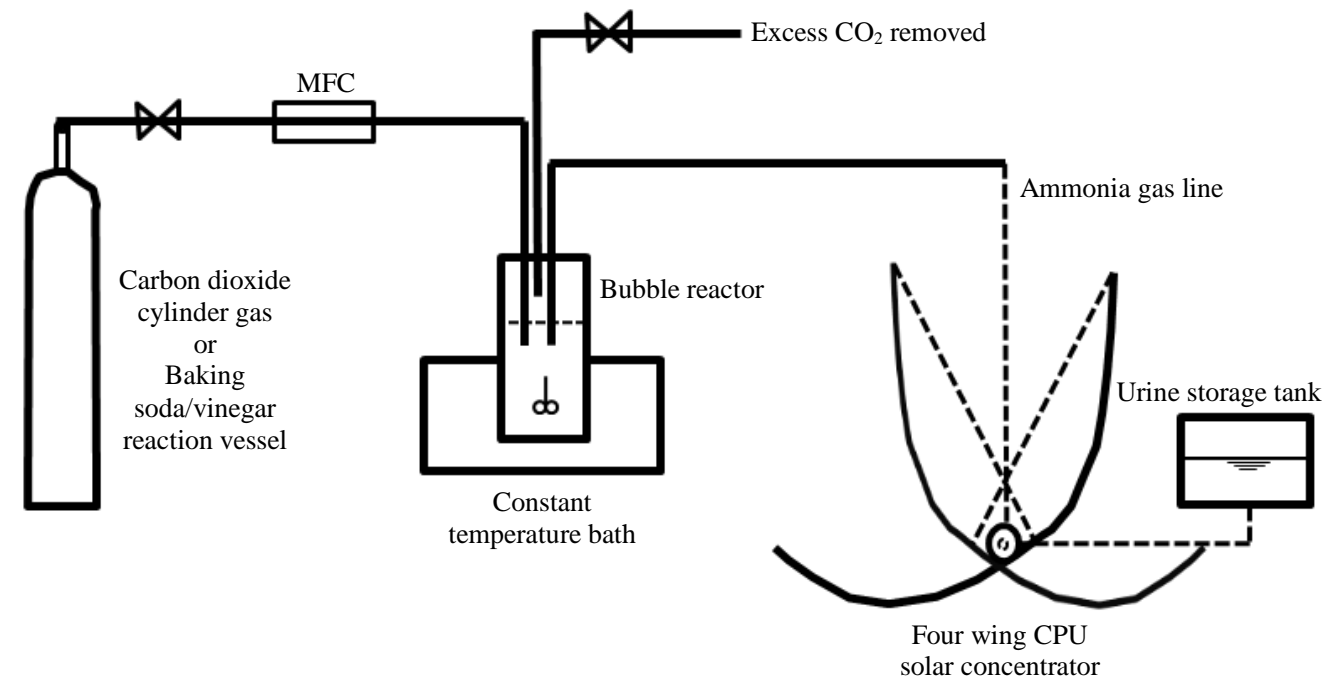

Fig. 4: A bubble reactor for the production of ammonium bicarbonate from urine and carbon dioxide powered by four wing compound parabolic concentrator

\section{Technical Setup for Ammonia Trapping from Urine Using Bicarbonate Chemistry}

The prototype set up for the trapping of ammonia from urine and concentrating the residual nutrients is shown in the schematic diagram of Fig. 4. The source of carbon dioxide considered is varied. This involves compressed gas cylinder, which may be locally available as industrial by-product, for example, from distilleries. In addition, other cheaper alternatives can be considered for the source of carbon dioxide, such as a reactor involving vinegar and baking soda. The pilot apparatus can be modified accordingly in order to accommodate these differing sources of carbon dioxide.
The amount of carbon dioxide supplied to the bubble reactor can be regulated using pressure or mass flow controller. In such a case, it will be assumed that the carbon dioxide is supplied in batch mode and there is no excess disposal/venting of the carbon dioxide out of the bubble reactor. This also means that the bubble reactor is a closed system and what is given off as carbon dioxide from the compressed cylinder (where it is used as a source) will be completely utilized for the reaction. In the option where venting line is provided for the excess carbon dioxide, it will be assumed the system is open yet the bubble reactor takes place under saturated conditions with respect to carbon dioxide. In any case, it is not desired to limit the reaction with shortage of carbon dioxide and such saturated conditions are necessary. 
Table 2: Parameters and their method of determination for the concentrated nutrient samples

\begin{tabular}{|c|c|c|}
\hline No. & Parameter & Method of determination \\
\hline$\overline{1}$ & Nitrogen & Kjeldahl method \\
\hline 2 & Phosphorus & Spectrophotometric method \\
\hline 3 & Potassium & $\begin{array}{l}\text { Flame photometric/(Atomic } \\
\text { absorption spectrometric- } \\
\text { AAS) method }\end{array}$ \\
\hline 4 & Electrical conductivity & $\begin{array}{l}\text { Potentiometric using } \\
\text { conductivity meter }\end{array}$ \\
\hline 5 & Total dissolved solids & Gravimetric method \\
\hline 6 & Sodium & $\begin{array}{l}\text { Flame photometric/ } \\
\text { AAS method }\end{array}$ \\
\hline 7 & Calcium & AAS method \\
\hline 8 & Magnesium & AAS method \\
\hline 9 & $\mathrm{pH}$ & $\begin{array}{l}\text { Potentiometric method } \\
\text { with glass electrode }\end{array}$ \\
\hline 7 & COD & Dichromate digestion method \\
\hline 9 & Chloride & $\begin{array}{l}\text { Argentometric titration/ion } \\
\text { chromatography }\end{array}$ \\
\hline
\end{tabular}

The carbon dioxide capture of ammonia is to be carried out by evaporative release of ammonia from the urine sample by heating achieved with the provision of a four wing compound parabolic concentrator (Fig. 4). The CPC design is a low cost reliable as well as renewable energy source that offers an advantage over other types of energy sources. A controlled flow of urine from the urine storage tank to the solar concentrator absorber pipe is made through gravity flow via transparent pipe. The volatile ammonia leaves the absorber pipe through a vertical pipe and enters the bubble reactor as shown in Fig. 4. The subsequent reaction of the ammonia released with external source of carbon dioxide provided in another vessel provided as a bubble reactor. The concentration of the remaining nutrients once the ammonia is captured is carried out by continuing the heating at boiling temperature of water. This will help in concentrating the remaining nutrients in the urine once the ammonia is volatilized and captured. The $\mathrm{pH}$ and temperature of the reaction will be monitored. In addition, the precipitated ammonium carbonate or bicarbonate will be filtered, dried, weighed and analysed for ammonia nitrogen using the procedure described in section 3.5.

The parameters given in Table 2 will help in assessing the nutrient content of the concentrated urine following the procedure described above. Nitrogen, phosphorus and potassium are the NPK nutrients directly needed by plants for growth. Following the experiment for concentration of urine and ammonia capture, analysis can be made of the concentrated samples for these parameters. The $\mathrm{pH}$ is a parameter that is necessary for monitoring the process in both the heating of the urine sample as well as reaction in the bubble reactor. The electrical conductivity and total dissolved solids are indirect indicators of the extent of salinity present in the soil, which can negatively affect the soil and plant growth both in the long and short term. Chemical Oxygen Demand (COD) is analysed to determine the organic matter present in the concentrated urine samples. The presence of organic matter helps in conditioning the soil, improving the permeability and water holding capacity of the soil to which nutrients generated from urine are applied as fertilizer. Analyses for sodium, magnesium and calcium will help in estimating the sodium absorption ratio of the concentrated nutrient. Chloride will be monitored as it can also negatively affect plant growth.

\section{Determination of the Ammonium Bicarbonate Produced}

The experimental method for the determination of ammonium bicarbonate can be carried out by determining the associated ammonia component through back-titration procedure (CSS, 1992). The ammonium bicarbonate crystal produced is distilled in alkaline solution and the distilled ammonia is absorbed in standard sulphuric acid solution. The excess sulphuric acid is back titrated with standard sodium hydroxide solution. The nitrogen present in ammonia will be calculated from the consumption of the standard sulphuric acid. An alternative procedure is mixing the ammonium bicarbonate product in excess sulphuric acid solution and titrating the unreacted sulphuric acid using sodium hydroxide (GB-3559-92, 1992).

Care should be taken through proper experimental set up, use of standard procedures for laboratory determination of parameters listed in Table 2 and calibration of the experiment against known standards. Experiments need to be repeatedly run under different environmental conditions and all information accompanying the experiments should be properly recorded to ensure traceability of the results obtained as well as help in the analysis and interpretation of data. All the urine samples collected should be treated as potential microbial risks and adequate precaution should be observed both during sample collection, sample transportation as well as experimental analysis

\section{Conclusion}

Nutrients derived from urine are considered as possible alternatives to commercial fertilizers that are expensive to produce and have high carbon foot print in production. Urine is self-sterilised and contains important nutrients needed for plant growth. Concentration of nutrients reduces transportation requirement, loss by leaching and ammonia volatilization as well as making the application of urine to agriculture aesthetically acceptable to farmers. A urine concentration technique that combines solar evaporation of urine with a cheap carbon dioxide trapping of the 
ammonia would be a suitable low cost alternative in which the ammonium bicarbonate produced can be suitably combined with the residue after evaporation to provide the needed ingredients for optimum plant growth. The ammonium carbonate produced provides both ammonium and carbon dioxide needed for plant growth. The process of heating can be powered by a solar concentrator, a renewable energy resource. During evaporation the heating eliminates pathogens as well as the structure of micro pollutants and cytotoxic agents that may pose health risk.

\section{Authors contributions}

All authors equally contributed in this work.

\section{Ethics}

This article is original and contains unpublished material. The corresponding author confirms that all of the other authors have read and approved the manuscript and no ethical issues involved.

\section{References}

Aage, H.K., B.L. Andersen, A. Blom and I. Jensen, 1997. The solubility of struvite. J. Radio Analytical Nuclear Chem., 223: 213-215. DOI: 10.1007/BF02223387

Alkhudhiri, A., N. Darwish and N. Hilal, 2012. Membrane distillation: A comprehensive review. Desalination, 287: 2-18.

DOI: $10.1016 /$ j.desal.2011.08.027

Antonini, S., M.A. Arias, T. Eichert and J. Clemens, 2012a. Greenhouse evaluation and environmental impact assessment of different urine-derived Struvite fertilizers as phosphorus sources for plants. Chemosphere, 89: 1202-1210.

DOI: $10.1016 /$ j.chemosphere.2012.07.026

Antonini, S., P.T. Nguyen, U. Arnold, T. Eichert and J. Clemens, 2012b. Solar thermal evaporation of human urine for nitrogen and phosphorus recovery in Vietnam. Sci. Total Environ., 414: 592-599.

DOI: $10.1016 /$ j.scitotenv.2011.11.055

Antonini, S., S. Paris, T. Eichert and J. Clemens, 2011. Nitrogen and phosphorus recovery from human urine by struvite precipitation and air stripping in Vietnam. CLEAN-Soil Air Water Pollut., 39: 1099-1104. DOI: 10.1002/clen.201100036

Bailly, M., 2002. Production of organic acids by bipolar electro dialysis: Realizations and perspectives. Desalination, 144: 157-162.

DOI: 10.1016/S0011-9164(02)00305-3

Baranov, V.K. and G.K. Melnikov, 1966. Study of the illumination characteristics of hollow focons. Sov. J. Opt. Technol., 33: 408-411. DOI: 10.1086/288114
Baranov, V.K., 1965. A paper in Russian that introduces certain properties of CPCs. Opt. Mekh. Prom., 6: 1-5.

Baranov, V.K., 1967. Device for restricting in one plane the angular aperture of a pencil of rays from a light source" (in Russian). Russian Certificate of Authorship 200530, Specification.

Başakçilardan-Kabakci, S., A.N. İpekoğlu and I. Talinli, 2007. Recovery of ammonia from human urine by stripping and absorption. Environ. Eng. Sci., 24: 615-624. DOI: 10.1089/ees.2006.0412

Behrendt, J., E. Arevalo, H. Gulyas, J. NiedersteHollenberg and A. Niemiec et al., 2002. Production of value-added products from separately collected urine. Water Sci. Technol., 46: 341-346.

DOI: $10.2166 /$ wst.2002.0698

Beler-Baykal, B., S. Bayram, E. Akkaymak and S. Cinar, 2004. Removal of ammonium from human urine through ion exchange with clinoptilolite and its recovery for further reuse. Water Sci. Technol., 50: 149-156. DOI: 10.2166/wst.2004.0371

Blöcher, C., C. Niewersch and T. Melin, 2012. Phosphorus recovery from sewage sludge with a hybrid process of low pressure wet oxidation and Nano-filtration. Water Res., 46: 2009-2019. DOI: $10.1016 /$ j.watres.2012.01.022

Bryant, D., 2004. The Chemistry of Phosphorus. In: Phosphorus in Environmental Technologies, Valsami-Jones, E. (Ed.), IWA Publishing, London, UK, ISBN-10: 1843390019, pp: 3-17.

CDC, 2000. Leptospirosis. Centers for Disease Control and Prevention.

Chariar, M., A. Rahman and R.S. Ramesh, 2011. Decision support in available urine harvesting technologies. Proceedings of the Sustainable Habitat-Incorporating 3rd International Conference on Modern Bamboo Structures, Dec. 9-11, New Delhi.

CSS, 1992. Soil agriculture chemical analytical method.

Di, H.J., K.C. Cameron, R.G. Silva, J.M. Russell and J.W. Barnett, 2002. A lysimeter study of the fate of $15-\mathrm{N}$ labelled nitrogen in cow urine with or without farm dairy effluent in a grazed dairy pasture soil under flood irrigation. J. Agric. Res., 45: 235-244. DOI: $10.1080 / 00288233.2002 .9513514$

Doyle, J.D. and S.D. Parsons, 2002. Struvite formation, control and recovery. Water Res., 36: 3925-3940. DOI: 10.1016/S0043-1354(02)00126-4

Durrant, A.E., M.D. Scrimshaw, I. Stratful and J.N. Lester, 1999. Review of the feasibility of recovering phosphate from wastewater for use as a raw material by the phosphate industry. Environ. Technol., 20: 749-758. DOI: 10.1080/09593332008616870

EAWAG, 2009. How to produce fertilizer from urine: Struvite. Brochure in English/Nepali, Swiss Federal Institute of Aquatic Science and Technology, Duebendorf. 
Esrey, S.A., I. Andersson, A. Hillers and R. Sawyer, 2001. Closing the loop, ecological sanitation for food security. Publications on Water Resources No. 18, UNDP, SIDA, Mexico.

Etter, B., E. Tilley, R. Khadka and K.M. Udert, 2011. Low-cost Struvite production using source-separated urine in Nepal. Water Res., 45: 852-862.

DOI: $10.1016 /$ j.watres.2010.10.007

Feachem, R.G., D.J. Bradley, H. Garelick and D.D. Mara, 1983. Sanitation and Disease-Health Aspects of Excreta and Wastewater Management. 1st Edn., World Bank, ISBN-10: 047190094X, pp: 501.

Feineigle, M., 2011. Urine: Closing the NPK loop. Permaculture Research Institute, Sweden.

Fewlwss, K.L., 2015. Considerations for implementing source separation and treatment of urine, grey water and backwater. MSc Thesis, Colorado State University, Fort Collins, Colorado.

Ganrot, Z., G. Dave and E. Nilssen, 2007. Recovery of N and $\mathrm{P}$ from human urine by freezing, Struvite precipitation and adsorption to Zeolite and active carbon. Bio. Res. Technol., 98: 3112-3121. DOI: $10.1016 /$ j.biortech.2006.10.038

Garnot, Z., (n.y.). Fertilizer products from human urine. Melica Environmental Consulting. Goeteborg.

GB-3559-92, 1992. Agriculture Ammonium Bicarbonate National Standard of China.

Ghosh, G.K., K.S. Mohan and A.K. Sarkar, 1996. Characterization of soil fertilizer $\mathrm{P}$ reaction products and their evaluation as sources of $\mathrm{P}$ for gram (Cicer arietinum L.). J. Nutrient Recycl. Agro Ecosyst., 46: 71-79. DOI: 10.1007/BF00210225

Grange, J.M and M.D. Yates, 1992. Survey of mycobacteria isolated from urine and the genitourinary tract in south-east England from 1980 to 1989. British J. Urol., 69: 640-646.

DOI: $10.1111 /$ j.1464-410X.1992.tb15638.x

Gulyas, H., S. Zhang and R. Otterpohl, 2014. Pretreating stored human urine for solar evaporation by lowtechnology ammonia stripping. J. Environ. Protect., 5: 962-969. DOI: 10.4236/jep.2014.511097

Heinonen-Tanski, H. and C. Van Wijk-Sijbesma, 2005. Human excreta for plant production. Bio. Technol. 96: 403-411. DOI: 10.1016/j.biortech.2003.10.036

Hinterberger, H. and R. Winston, 1966a. Efficient light coupler for threshold Cerenkov counters. Rev. Sci. Instrum., 37: 1094-1095. DOI: 10.1063/1.1720428

Hinterberger, H. and R. Winston, 1966b. Gas counter with optimized light-collecting efficiency. Proceefings of the International Conference Instream High Energy Physice.

Höglund, C., 2001. Evaluation of microbial health risks associated with the reuse of source separated human urine. PhD Thesis, Department of Biotechnology, Royal Institute of Technology, Stockholm, Sweden.
Höglund, C., N. Ashbolt, T.A. Stenström and L. Svensson, 2002. Viral persistence in sourceseparated human urine. Adv. Environ. Res., 6: 265-275. DOI: 10.1016/S1093-0191(01)00057-0

Höglund, C.E. and T.A.B. Stenström, 1999. Survival of cryptosporidium parvum oocysts in source separated human urine. Canadian J. Microbiol., 45: 740-746. DOI: $10.1139 /$ w99-066

Jönsson, H., B. Vinnerås, C. Höglund, T.A. Stenström and G. Dalhammar et al., 2000. Recycling source separated human urine.

Karak, T. and P. Bhattacharyya, 2011. Human urine as a source of alternative natural fertilizer in agriculture: A flight of fancy or an achievable reality. Res. Conser. Recycl., 55: 400-408. DOI: $10.1016 /$ j.resconrec.2010.12.008

Karli, M., 2010. Nutrient recovery from urine and struvite production effluent using aquatic plants in Nepal. BSc Thesis, ZHAW (Zurich university of applied sciences), Wädenswil, in collaboration with Eawag (Swiss federal institute of aquatic science and technology), Dübendorf and Kathmandu.

Keshay, R.A and Z.S. Chen, 2011. Combining compost with urea: Nitrogen and phosphorus recovery by cabbage and leaching under imposed high rainfall condition in the greenhouse. Sci. Res. Essays, 6: 819-829.

Larsen, T.A., A.C. Alder, R.I.L. Eggen, M. Maurer and J. Lienert, 2009. Source separation: Will we see a paradigm shift in wastewater handling. Environ. Sci. Technol., 43: 6121-6125.

DOI: $10.1021 / \mathrm{es} 803001 \mathrm{r}$

Lee, S.I., S.Y. Weon, C.W. Lee and B. Koopman, 2003. Removal of nitrogen and phosphate from wastewater by addition of bittern. Chemosphere, 51: 265-271.

DOI: 10.1016/S0045-6535(02)00807-X

Les, D.H., J. Crawford, E. Landolt, J.D. Gabel and R.T. Kimball, 2002. Phylogeny and systematics of Lemnaceae, the Duckweed Family. Syst. Bot., 27: 221-240.

Liu, H., S. Grot and B.E. Logan, 2005. Electrochemically assisted microbial production of hydrogen from acetate. Environ. Sci. Technol., 39: 4317-4320. DOI: 10.1021/es050244p

Liu, K., Q. He, M. Chen, L. Meng and W. Pan, 2004. Study on carbon dioxide removal from flue gas by absorption of aqueous ammonia. Institute Combustion Science Environment Technology Western Kentucky University, Bowling Green, KY.

Logan, B., D. Call, S. Cheng, H. Hamelers and T. Sleutels et al., 2008. Microbial electrolysis cells for high yield hydrogen gas production from organic matter. Sci. Technol., 42: 8630-8640.

DOI: $10.1021 / \mathrm{es} 801553 \mathrm{z}$ 
Makaya, J.M., A. Savadogo, M.K. Somda, J.B. Bour and N. Barro et al., 2014. Quality of human urine used as fertilizer: Case of an ecological sanitation system in Ouagadougou Peri-Urban Areas-Burkina Faso. J. Environ. Protect., 5: 467-474.

DOI: $10.4236 /$ jep.2014.56049

Mansi, G.S., P.K. Shah, M.P. India, 2013. Design and development of compound parabolic concentrating solar collector with flat plate absorber. Int. J. Innova. Res. Sci. Eng. Technol.

Maurer, M., J. Muncke and T.A. Latseon, 2002. Technologies for Nitrogen Recover and Reuse. In: Water Recycling and Resource Recovery in Industry. Lens, P., L.H. Pol, P.A. Wilderer and T. Asano, (Eds.), IWA Publishing, London. Publisher IWA Publishing, ISBN 1843390051, pp: 677.

Maurer, M., W. Pronk and T.A. Larsen, 2006. Treatment processes for source-separated urine. Water Res., 40: 3151-3166. DOI: 10.1016/j.watres.2006.07.012

Mehta, C.M., W.O. Khunjar, V. Nguyen, S. Tait and D.J. Batston, 2015. Technologies to recover nutrients from waste streams: A critical review. Environ. Sci. Technol., 45: 385-427.

DOI: $10.1080 / 10643389.2013 .866621$

Miso, A. and D. Sphuler, 2009. Fertilizer from Urine (Struvite).

Morales, N., M.A. Boehler, S. Buettner, C. Liebi and H. Siegrist, 2013. Recovery of $\mathrm{N}$ and $\mathrm{P}$ from urine by Struvite precipitation followed by combined stripping with digester sludge liquid at full scale. Water, 5: 1262-1278. DOI: 10.3390/w5031262

Münch, E.V. and K. Barr, 2001. Controlled struvite crystallisation for removing phosphorus from anaerobic digester side streams. Water Res., 35: 151-159. DOI: 10.1016/S0043-1354(00)00236-0

Musabaev, T., 2015. Low cost domestic struvite technology for the treatment of source separated human urine from Urine Diverting Dry Toilets (UDDT's) in rural areas of Kyrgyzstan. Proceedings of the 5th International Dry Toilet Conference, (DTC' 15), Finland.

Nelson, N.O., R.L. Mikkelsen and D.L. Hesterberg, 2003. Struvite precipitation in anaerobic swine lagoon liquid: Effect of $\mathrm{pH}$ and $\mathrm{Mg}$ : $\mathrm{P}$ ratio and determination of rate constant. Bio Res. Technol., 89: 229-236. DOI: 10.1016/S0960-8524(03)00076-2

Niewersch, C., A.L. Battaglia Bloch, S. Yüce, T. Melin and M. Wessling, 2014. Nano filtration for the recovery of phosphorus-development of a mass transport model. Desalination, 346: 70-78.

DOI: 10.1016/j.desal.2014.05.011

Othmer, K., 1992. Encyclopedia of Chemical Technology. 4th Edn., John Wiley and Sons, New York.
Pinnekamp, K., K. Gethe and K. Herbst, 2007. Human urine-decomposition processes and nutrient recovery. Institute of Environmental Engineering (ISA), RWTH Aachen, Germany.

Ploke, M., 1967. Lichtführungseinrichtungen mit starker Konzentrationswirkung. Optik, 25: 31-43.

Prabhu, M. and S. Mutnuri, 2014. Cow urine as a potential source for Struvite production. Int. J. Recycl. Waste Agric., 3: 1-12. DOI: 10.1007/s40093-014-0049-z

Pronk, W. and D. Koné, 2010. Options for urine treatment in developing countries. Desalination, 251: 360-368. DOI: 10.1016/j.desal.2008.05.076

Pronk, W., H. Palmquist, M. Biebow and M. Boller, 2006. Nano filtration for the separation of pharmaceuticals from nutrients in source-separated urine. Water Res., 40: 1405-1412.

DOI: $10.1016 /$ j.watres.2006.01.038

Rabl, A., 1976b. Optical and thermal properties of compound parabolic concentrator. Solar Energy, 18: 497-511. DOI: 10.1016/0038-092X(76)90069-4

Rabl, A., 1976a. Comparison of solar concentrators. Solar Energy, 18: 93.

DOI: $10.1016 / 0038-092 \mathrm{X}(76) 90043-8$

Rahman, M.A., S.R. Sakthivel and V.M. Chariar, 2011. Decision support in available urine harvesting technologies: Technical and economical analysis. Proceedings of the 3rd International Conference on Modern Bamboo Structures, (MBS, 11), New Delhi, pp: 9-11.

Ronteltap, M., 2009. Phosphorus recovery from source-separated urine through the precipitation of Struvite. PhD Thesis, Swiss Federal Institute of technology, Zurich.

Ronteltap, M., M. Maurer, R. Hausherr and W. Gujer, 2010. Struvite precipitation from urine-Influencing factors on particle size. Water Res., 44: 2038-2046. DOI: $10.1016 /$ j.watres.2009.12.015

Rozendal, R., H. Hamelers, G. Euverink, S. Metz and C. Buisman, 2006. Principle and perspectives of hydrogen production through bio catalysed electrolysis. Int. J. Hydro. Energy, 31: 1632-1640. DOI: 10.1016/j.ijhydene.2005.12.006

Ryu, H.D., C.S. Lim, M.K. Kang and S.I. Lee, 2012. Evaluation of struvite obtained from semiconductor wastewater as a fertilizer in cultivating Chinese cabbage. J. Hazardous Materials, 221: 248-255. DOI: 10.1016/j.jhazmat.2012.04.038

Sanchez, M., I.G. Martinez, E.A. Rincon, M.A. Duran, 2014. Design and thermal-optic analysis of an ultrasolar concentrator. Energy Proced., 57: 311-320. DOI: 10.1016/j.egypro.2014.10.036

Schuen, R., J. Parkinson and A. Knapp, 2009. Study for financial and economic analysis of ecological sanitation in sub-Saharan Africa. Water Sanitation Program-Africa, World Bank, Nairobi, Kenya. 
Sendrowski, A. and T.H. Boyer, 2013. Phosphate removal from urine using hybrid anion exchange resin. Desalination, 322: 104-112.

DOI: $10.1016 /$ j.desal.2013.05.014

Siegrist, H., M. Laureni and K.M. Udert, 2013. Transfer into the Gas Phase: Ammonia Stripping. In: Source Separation and Decentralization for Wastewater management, Larsen, T.A., K.M. Udert and J. Lienert (Eds.), IWA Publishing, ISBN 1843393484, pp: 520.

Srinivasamurthy, C.A., 2009. Human urine as an alternative to chemical fertilizers in crop production. Department Soil Science and Agricultural Chemistry, University of Agricultural Sciences, Bengaluru, Karnataka, India.

Steén, I. and P. Steen, 1998. Phosphorus availability in the 21st century: Management of a non-renewable resource. Phosphorus Potassium, 217: 25-31.

Thorndahl, U., 1993. Nitrogen removal from returned liquors. J. Inst. Water Environ. Manage., 7: 492-496. DOI: 10.1111/j.1747-6593.1993.tb00877.x

Tice, R.C., 2014. Sustainable wastewater treatment: Nutrient separation, energy recovery and water reuse. MSc Thesis, University, Canada.

Tidåker, P., B. Mattsson and H. Jönsson, 2007. Environmental impact of wheat production using human urine and mineral fertilisers-A Scenario Study. J. Cleaner Product., 15: 52-62.

DOI: 10.1016/j.jclepro.2005.04.019

Tilley, E., B. Gantenbein, R. Khadka, C. Zurbrugg and K. Udert, 2009. Social and economic feasibility of Struvite recovery from Urine at the community level in Nepal. Proceedings of the Presented at the International Conference on Nutrient Recovery from Wastewater Streams, (RWS, 09), Vancouver, Canada.

Tiruneh, A.T., K. Kassa and T. Tesseme, 2011. Concentration of ammonia-nitrogen generated from UDDT toilets using adsorption and solar evaporation techniques. Proceedings of the 2nd National Research Symposium on Research for Socio-Economic Transformation, (SET, 11), Debremarkos, Ethiopia.

Tiruneh, A.T., W.N. Ndlela, T.H. Gadaga, T. Debessai and J. Heikilla, 2017. A four-wing Compound Parabolic Concentrator (CPC) design for heating and sanitization of waste products. J. Power Energy Eng., 5: 18-35. DOI: 10.4236/jpee.2017.53002

Tortora, G.J., B.R. Funke and C.L. Case, 1992. Microbiology: An introduction. The Benjamin/Cummings Publishing Company, Inc., Redwood City, California, USA.

Udert, K.M. and M. Wächter, 2012. Complete nutrient recovery from source-separated urine by nitrification and distillation. Water Res., 46: 453-464.

DOI: $10.1016 /$ j.watres.2011.11.020
UN, 1999. The world at six billion. United Nations Population Division.

Vinnerås, B., A. Nordin, C. Niwagaba and K. Nyberg, 2008. Inactivation of bacteria and viruses in human urine depending on temperature and dilution rate. Water Res., 42: 4067-4074. DOI: 10.1016/j.watres.2008.06.014

Wang, X., Y. Wang, X. Zhang, H. Feng and C. Li et al., 2013 Phosphate recovery from excess sludge by Conventional Electro Dialysis (CED) and Electro Dialysis with Bipolar Membranes (EDBM). Industrial Eng. Chem. Res., 52: 15896-15904. DOI: $10.1021 / \mathrm{ie} 4014088$

Winston, R., 1970a. Light collection within the framework of geometrical optics. J. Opt. Soc. Am., 60: 245-247. DOI: 10.1364/JOSA.60.000245

Winston, R., 1974b. Principles of solar concentrator of a novel design. Solar Energy, 16: 89-95. DOI: 10.1016/0038-092X(74)90004-8

Winston, R., C.C. Juan and P. Benítez, 2005. NonImaging Optics. 1st Edn., Academic Press, ISBN-10: 0127597514, pp: 497.

Xie, M., H.K. Shon and S.R. Gray, 2015. Membranebased processes for wastewater nutrient recovery: Technology, challenges and future direction. Water Res., 89: 210-221. DOI: 10.1016/j.watres.2015.11.045

Zarebska, A., D.R. Nieto, K.V. Christensen and B. Norddahl, 2014. Ammonia recovery from agricultural wastes by membrane distillation: Fouling characterization and mechanism. Water Res., 56: 1-10.

DOI: $10.1016 /$ j.watres.2014.02.037

Zhang, Y., S. Paepen, L. Pinoy, B. Meesschaert and B. Van der Bruggen, 2012. Electrodialysis: Fractionation of divalent ions from monovalent ions in a novel electro dialysis stack. Separation Purification Technol., 88: 191-201.

DOI: 10.1016/j.seppur.2011.12.017

Zhuang, Q., B. Clements and Y. Li, 2012. From ammonium bicarbonate fertilizer production process to power plant $\mathrm{CO}_{2}$ capture. Int. J. Greenhouse Gas Control, 10: 56-63.

DOI: 10.1016/j.ijggc.2012.05.019 